\title{
Curriculum History in Europe: A Historiographic Added Value
}

\author{
Daniel Tröhler
}

\begin{abstract}
This article advocates for a particular understanding of curriculum history that enables educational research to emancipate itself from national idiosyncrasies. It suggests focusing, in the frame of a cultural history, on the interrelation between the constitutions, which define the ideal social order and the envisaged ideal citizens, and the curriculum, which provides "educational opportunities" - that is, pre-organised or preconfigured pathways of educational careers. The article thereby stresses that the fundamental notions of this research program - nation, society, and citizen - need to be handled as floating signifiers that are materialised differently in the various individual nation-states. The article argues that against this background, a European education history that respects national or cultural distinctions without getting trapped by national idiosyncrasies is possible.
\end{abstract}

Keywords • long nineteenth century, nation-state, curriculum, society, citizenship, historiography

Within the long nineteenth century between the foundation of the United States of America in 1787 and the foundation of Finland after World War I, the territorial landscape of the Western world changed fundamentally. As compared to the time before, the Ancien Regime, territorial entities were clearly defined and mutually accepted by international treaties, guaranteeing the sovereignties of these territorial entities called nation-states. This sovereignty of these nation-states was and is still far-reaching, in some cases allowing cruelest regimes to proceed in their modes of governance. Visible international interventions happen only in very rare cases, at best backed up by resolutions of the globally sanctified United Nations organisation, which, as the name suggests, unites the nation-states without - in principle - questioning their sovereignty.

Both the concept of the nation and the concept of the state are older than the compound noun "nation-state." In its interconnection nation-state unites feelings of commonality and togetherness with political principles and institutions, thereby ensuring the people a permanent and ordered coexistence in a clearly defined territory, whose boundaries should be ideally just the boundaries of the nation as a community. Nation-state thus combines territorial power politics (and its tenden-

Revised version of a keynote paper presented August 20, 2015, at the Sixth Nordic Conference on the History of Education, 20-21 August 2015, Uppsala University, Sweden. Some more theoretical aspects of this approach to curriculum history have been more broadly discussed in Daniel Tröhler, "Curriculum History or the Educational Construction of Europe in the Long Nineteenth Century," European Educational Research Journal 15, no. 3 (2016), 279-97.

Daniel Tröhler is Professor of Educational Sciences at the Faculty for Language and Literature, Humanities, Arts and Education, University of Luxembourg.

Email: daniel.troehler@uni.lu 
cy to make social distinctions) and the idea of community and unity. However, the idea of community and unity behind the concept "nation" had not been an invention of power-holders but rather more a creation by intellectuals, with their obvious longings for collective identity. ${ }^{1}$ Often the idea of the nation was derived from the commonality of language, sometimes of a common history, or a shared religion, or a combination of them. In any case, it was derived from narratives that could be easily defined as distinction from others, and often this distinction was understood as being superior. In combination with the state, this idea of the nation or the national identity and superiority became an explosive mixture on the global scene, and it is hard to imagine that the two world wars would have occurred without the existence of the nation-states.

The notion "existence of the nation-states" refers to two different but interconnected dimensions of institutionalisation. For one, it refers to the formal-political institutionalisation of the nation-state with regard to the constitution and the laws, which provide normative-organisational fundaments of the coexistence as it is expressed between the individuals, organisations, and political authorities. For another, the notion "existence of the nation-states" refers to cultural or mental institutionalisations with regard to the people's feelings of togetherness, which provide a kind of mutual sympathy or even patriotism. This latter dimension, the cultural or mental disposition of the individuals to have this feeling and an identity of commonality with some people - and at the same time to see others' foreignness - was not in any case given either, but had to be made. The actual materialisation of this "making" was the citizen, or, more precisely, the citizens.

The overall thesis of this article is that this making of the citizens was prominently assigned to the public school and its curriculum. Here, "curriculum" is understood as "educational opportunities" provided by the state (public authority), leading to pre-organised or preconfigured pathways of educational careers, structured in different school subjects and their (selected) knowledge, in grades and school tracks, whereby particular transition regimes decide on the student's progress between the grades $^{2}$ and access to one of the different school tracks or to further education on the tertiary education level. ${ }^{3}$ In contrast to some foci in curriculum history, the emphasis here is less on what students learn at school and more on what kind of persons students are meant to become while passing through these provided pathways of educational careers. In that sense, the understanding of curriculum is directed towards the organisational structuring of currere, the infinitive form of curriculum, as Pinar suggested. ${ }^{4}$

Referring to curriculum history has at the same time an advantage and a disadvantage, however. The fact is that curriculum history, together with curriculum studies in general, is in its origin and in a dominant way an American tradition of research, a particular result of a particular way of doing research in the field of education. The disadvantage with the origins of this American offspring is that curriculum studies and curriculum history usually bear the cultural idiosyncrasies or burdens

1 Hagen Schulze, Staat und Nation in der europäischen Geschichte (Munich: Beck, 1994).

2 For instance, in the case of repetition.

3 Alternatively to vocational training.

4 William F. Pinar, What is Curriculum Theory? Second Edition (New York: Routledge, 2012), 43. 
of the American aspirations behind curriculum research. In contrast, the advantage is that once these cultural burdens are identified, and by that relativised, curriculum research may well be more than a credible way to do educational research, and that is my thesis, combining history and philosophy of education in the frame of a cultural approach to educational institutions and allowing at the same time international comparison. This could serve as a way to conduct an international comparative education history, for instance of Europe.

The purpose of this article is to elaborate, in six steps, this idea of the historiographic added value of this particular understanding of curriculum history. First, I aim to discuss the danger of an ideological trap by advocating curriculum history, and then I suggest a methodological strategy to de-contextualisation central notions, such as, among others, the notion of the "citizen." I intend, then, to rehabilitate the importance of the role that constitutions play in education from a formalistic legal point of view that creates the "citizens", in order to draw on a selection of European examples that depict the importance of constitutions. I then indicate that a constitutional state needed not just formally defined citizens but loyal citizens that accept(ed) social distinctions. And in the last step, I come back to the question as to how we may do international research in education as curriculum research that refrains from universalizing cultural idiosyncrasies to the whole world.

\section{Ideological traps: Curriculum vs Didaktik and citizen vs Bildung}

The article starts out from the assumption that curriculum studies/curriculum history is a particular U.S. way of understanding the organisation of schooling and instruction. This particular way became distinctly visible in the times when the United States was facing challenges triggered by massive immigration, modernisation (in terms of commercialisation of life and the growth of large cities), and the experiences of the First World War. It seems to be no coincidence that the reflection upon schooling emphasizing curriculum was directed towards the "others," with the aim to make them the "same"; in this respect concerned citizens developed Methods of Teaching Patriotism in the Public School (Balch, 1889) to be applied to the immigrants to make them Americans. The emergence of teaching patriotism or civic virtues is embedded in the age labeled as Progressivism, a time when, among other changes, the social sciences were established at the modern research universities in order to face these societal challenges brought about by immigration but also by the unmatched growth of the big cities. Pragmatism was to become a most prominent responsive philosophy or theory, resulting from the concerns of the time, ${ }^{5}$ and the new social sciences departments developed programs in Education for Citizenship in a Democracy ${ }^{6}$ and published books like The American Citizen in response to the "growing demand for the more adequate teaching of morals in the schools, especially with reference to the making of good citizens." Accordingly, the schools started to implement "social studies" in their curricula to reinforce civics and social responsibility as democratic

5 Daniel Tröhler, "The Technological Sublime and Social Diversity: Chicago Pragmatism as Response to a Cultural Construction of Modernity," in Pragmatism and Modernities, ed. Daniel Tröhler, Thomas Schlag, and Fritz Osterwalder (Rotterdam: Sense Publishers, 2010), 25-44.

6 Frederic P. Woellner, Education for Citizenship in a Democracy: A Text-book for Teachers in the Elementary Schools (New York: Charles Scribner's Sons, 1923).

7 Charles Fletcher Dole, The American Citizen (Boston: D. C. Heath, 1892), v. 
desiderata. ${ }^{8}$ The time was concerned with the curricular question of the Making of Citizens, ${ }^{9}$ and in this context the National Society for the Study of Education devoted one of its yearbooks to the Foundations and Technique of Curriculum Construction (NSSE, 1926), ${ }^{10}$ a volume that was followed by another one focusing on the curriculum as a means of citizenship education. ${ }^{11}$

In Europe, similar endeavors to (re-)connect education to democratic citizenship are found only in exceptional cases. Somewhat similar discussions in Europe focused primarily on school-subject didactics, ${ }^{12}$ a particular focus which makes an international comparative discussion on curriculum difficult, ${ }^{13}$ all the more so when we consider that against the background of the culturally non-negotiable epitome of Bildung, ${ }^{14}$ in Germany questions of schooling and curriculum have always had a difficult standing in the academic community. ${ }^{15}$ These difficulties became evident some 20 years ago in a most revealing cross-Atlantic encounter between scholars from Norway, Germany, and the United States, who met for conferences called Didaktik meets Curriculum (Hopmann \& Riquarts, 1995; Gundem \& Hopmann, 1998; Westbury, Hopmann, \& Riquarts, 2000): The major concern was to understand why, for instance, the "correct" translation of "Didaktik" into English as "didactics" is not helpful, or even misleading, and why vice versa the "correct" translation of "curriculum" as "Lehrplan" is not helpful either, for Lehrplan would rather have to be translated into "course of study."

This Didaktik meets Curriculum discussion has certainly not yet received the attention it deserves. Nevertheless, on the level intended by the organisers of the encounter, the discussion made evident differences visible that complicate international research significantly up to today. On another, not explicitly addressed level, the

8 Michael Lybarger, “Origins of the Modern Social Studies: 1900-1916," History of Education Quarterly 23, no. 4 (1983), 455-68.

9 Joseph Gregoire de Roulhac Hamilton and Edgar W. Knight, The Making of Citizens (Chicago: McClurg \& Co., 1922).

10 NSSE, Foundations and Technique of Curriculum Construction (Bloomington: Public School Publishing Company, 1926).

11 Holis L. Caswell and Doak S. Campbell, Curriculum Development (New York: American Book Company, 1935).

12 Bjørg B. Gundem, "Understanding European Didactics," in Routledge International Companion to Education, ed. Bob Moon, Sally Brown, and Miriam Ben-Peretz (London: Routledge, 2000), 23562; Tero Autio, Between and Beyond the German Didaktik and Anglo-American Curriculum Studies (Mahwah: Lawrence Erlbaum Associates, 2006).

13 Stefan Hopmann and Kurt Riquarts, Didaktik und, oder Curriculum: Grundprobleme einer internationalen vergleichenden Didaktik (Weinheim, Germany: Beltz, 1995); Ian Westbury, Stefan Hopmann, and Kurt Riquarts, eds., Teaching as a Reflective Practice: The German Didaktik Tradition (Mahwah: Lawrence Erlbaum Associates, 2000); see also William F. Pinar, The Character of Curriculum Studies: Bildung, Currere, and the Recurring Question of the Subject (New York: Palgrave Macmillan, 2011).

14 Rebekka Horlacher and Andrea De Vincenti, "From Rationalist Autonomy to Scientific Empiricism: A History of Curriculum in Switzerland," in International Handbook of Curriculum Research, 2nd ed., ed. William F. Pinar (New York: Routledge, 2013), 476-92.

15 Rebekka Horlacher, The Educated Subject and the German concept of Bildung: A Comparative Cultural History (New York: Routledge, 2016).

16 Stefan Hopmann and Bjørg B. Gundem, "Didaktik Meets Curriculum. Towards a New Agenda," in Didaktik and/or curriculum. An international dialogue, ed. Bjørg B. Gundem and Stefan Hopmann (Frankfurt, Peter Lang, 1998), 331-54. 
discussion partners represented not only different parts of the world but also the two major cultural driving forces that were available at the time when the nation-states evolved and were in need of educational theories. These theories later on crystallised into the contrast at stake, curriculum versus Didaktik.

These two major cultural driving forces in the form of educational theories had been developed in Protestant circles in the course of the 18th century, when political, economic, and social transformations as well as perceptions of progress and an open future had given rise to the need to address both coping with changing living conditions and guaranteeing of moral behavior. For concerned Protestants, exposing people to a capitalizing world meant developing educational strategies that aimed at morally strengthening the soul of adolescents. The two major theories at hand in the 18th century resulted from the two different Protestant traditions, German Lutheranism, which spread to the Nordic Countries, and Swiss Reformed Protestantism, a combination of Zwinglianism and Calvinism, which spread via England to the United States. Both traditions relied on the Protestant interpretation of the soul of the individual as the pivotal point of mastering the (moral) challenges of the future, but they differed in their political theories and hence in their visions of the future citizen. In the one case it was the virtuous citizen, and in the other it was Bildung. ${ }^{17}$ Whereas the Reformed Protestant ideal of the virtuous citizen was directed at contributing to the polis, that is, the existing or becoming nation-state, the evangelical Protestant ideal of Bildung remained focused on the cosmopolitan vision of mankind in general (Menschheit). ${ }^{18}$

The distinction between the virtuous citizen and the ideal of Bildung was mirrored in the educational programs. In the case of the virtuous citizen the "curriculum" could, beyond moral and Christian instruction, include modern languages rather than the "dead" languages, rhetoric (enabling the future citizen to speak in public), history (to convey a sense of liberty and tyranny), chemistry (useful for agriculture and manufacturing), and homeland policy (to make clear the obligations and rights of every citizen). ${ }^{19}$ In this sense, citizenship is not cosmopolitan but restricted to the concrete fatherland, as, for instance, Rousseau had emphasised over and over and as Jefferson wrote in letter from Paris to John Banister on October 15, 1785, warning against sending American sons to Europe: "He acquires a fondness for European luxury and dissipation, and a contempt for the simplicity of his own country; he is fascinated with the privileges of the European aristocrats, and sees, with abhorrence, the lovely equality which the poor enjoy with the rich, in his own country (...) It appears to me then, that an American coming to Europe for education, loses in his knowledge, in his morals, in his health, in his habits, and in his happiness." 20

In contrast, the "curriculum" of the Lehrplan dedicated to ideal of Bildung aimed deliberately at the "opposite." Expressed in the Lehrplan, this idea sharply separates

17 Daniel Tröhler, Languages of Education: Protestant Legacies, National Identities, and Global Aspirations (New York: Routledge, 2011).

18 Horlacher (2016).

19 Benjamin Rush, "Of the Mode of Education Proper in a Republic," in The Selected Writings of Benjamin Rush, ed. Dagobert D. Runes (New York: Philosophical Library, 1947), 90-100. (Original date of publication 1786)

20 Thomas Jefferson, "Letter to John Banister Jr., dated 15 October 1785," in Thomas Jefferson: Writings, ed. M. D. Peterson (New York: Literary Classics of the United States, 1984), 837-40. 
education (Bildung or Allgemeinbildung) from any kind of useful of vocational training (Ausbildung). "All schools" of the state may, as Humboldt stated, "only focus on general Bildung of the human character," and any educational concern connected to the needs of real life must be separated from it. ${ }^{21}$ Any kind of useful training has to be postponed to the stage when every human being has been first educated as a human character. According to Humboldt, general Bildung has to empower, purify, and order human forces in order to perfect the human mind/soul (Gemüt). The ancient Greeks and their ideal of aesthetics are identified as the model, ideally to be learned by every individual: "In this way, having learned Greek would be just as useful for the carpenter as would carpentry for the scholar." ${ }^{22}$ Against this background, it is no coincidence that the German Gymnasium was built on Greek and Latin as major school subjects and that this "curriculum" was clearly distinct from the Swiss Gymnasium, which represented the Reformed Protestant development of education. ${ }^{23}$

It is precisely this orientation towards the aesthetic transformation of the inward soul that prevented curricular discussions on useful school subjects, and it is here that the notion of Didaktik comes into play. As the "godfather" of German Didaktik Wolfgang Klafki said Didaktik was to be strictly separated from any questions of method, the actual act of teaching. ${ }^{24}$ Didaktik is the ultimate touchstone to define any potential teaching content as real educational school content to be taught in class. "An educational content is not an external, simply 'given' substance," says Klafki, and quoting Erich Weniger, he adds that "in this substance is an organic power, which, once incorporated in the mind (Geist), starts to determine the perceptions and thoughts, conforms them and effects their inward configuration," ${ }^{25}$ that is, the inward Bildung of the person, representing a "self-contained entity like a sonata, [... $]$ a poem, a cultural epoch." ${ }^{\prime 2}$

Didaktik, therefore, is related to the idea of Bildung, which represents the educational aspiration of evangelical Protestantism, whereas Reformed Protestantism aimed at the virtuous citizens, who were to be made by what is called "curriculum." It may be a coincidence that the notion of curriculum appeared for the first time in 1576 in the writings of the French Calvinist Petrus Ramus, who was killed in the St. Bartholomew's Day massacre in 1572, and then appeared again in Leiden and Glasgow, which were both strongholds of the training of Calvinist priests. ${ }^{27} \mathrm{Be}$ it as it is, the adherence of the German discussion to Didaktik indicates that "curriculum" may indeed be culturally biased, and the ideal of Bildung indicates cultural biases, too.

21 Wilhelm von Humboldt, "Der Königsberger und Litauische Schulplan," in Wilhelm von Humboldt: Werke in fünf Bänden, Band IV (Darmstadt: Wissenschaftliche Buchgesellschaft, 1963), 168-95. (Original date of publication 1809)

22 Humboldt (1963), 189.

23 Daniel Tröhler, "Between Ideology and Institution: The Curriculum of Upper-Secondary Education," Journal of Curriculum Studies 41, no. 3 (2009), 393-408.

24 Wolfgang Klafki, "Didaktische Analyse als Kern der Unterrichtsvorbereitung," in Die deutsche Schule 50 (1958), 451.

25 Klafki (1958), 454.

26 Klafki (1958), 455.

27 David Hamilton, Towards a Theory of Schooling (Philadelphia: Falmer Press, 1989), 43. 


\section{Methodological detours: De-contextualisations}

Accordingly, in Europe a more or less continuous research tradition under the catchword "curriculum" has never really existed. Even interest in relevant transatlantic research has been rather marginal, which is a pity, for curriculum studies or curriculum history does indeed offer many advantages for the benefit of a better theoretical quality in education research - if it overcomes cultural biases that obviously will prove to be an obstacle to an unbiased international research approach.

To explore the advantages of curriculum history I will be taking the example of Europe, foremost in the nineteenth century. To do so I need to use a particular method that may stand in exact opposition to what we usually teach and ask for: We need to de-contextualise (at least) three core concepts that act as taken-for-granted assumptions in today's curriculum research and that are at risk of being extrapolated to the whole world as universal categories in research and policy. This hegemonic cultural extrapolation can be witnessed in the so co-called neo-institutionalised world culture theory, with their claim of a "world curriculum" of the "global village," indicating the "relative unimportance of the national, so far as mass curricular outlines go." ${ }^{\text {28 }}$ In contrast to this in fact hegemonic interpretation, I suggest that we must first de-contextualise these central concepts in curriculum studies in order to generate floating signifiers that then can, in a second step, be (re-)contextualised in the respective cultural idiosyncrasies around the world, or at least in Europe or the Nordic States.

The three concepts that I wish to de-contextualise first are "citizen," "society," and "nation." These are central concepts in curriculum studies that are closely linked to American culture and are accordingly culturally biased. At the basis of this bias lies the U.S. idea that curriculum adds to progress, which is seen as enhancing democra$\mathrm{cy}$, as may be seen in one of the most popular books on curriculum history, the book History of the School Curriculum published by Daniel Tanner and Laurel Tanner. ${ }^{29}$

To de-contextualise these three notions from this original context and to create floating signifiers, we may understand:

- a nation or a nation-state as a recognised territorial and political entity consolidated by a constitution,

- a society as the body of people living within this territory, and

- a citizen as a privileged recognised member of this society, as a rule distinct from an alien or foreigner.

Starting with floating signifiers rather than with culturally biased concepts (for instance, the democratic citizen) enables us to better conduct international research without getting trapped in the hegemonic aspirations of one culture that obviously dominates the world. The artifact of fundamental cultural differences was well known 100 years ago, when the United States did not yet play the global role that it has had since 1945, as we may learn from Mark, a lecturer at the University of Manchester in England: “'American citizen' is America's watchword. In that name a Western civilisation has to be built up. Our elementary schools might well borrow

28 John Meyer, "Introduction," in School Knowledge for the Masses: World Models and National Primary Curricular Categories in the Twentieth Century, eds. John W. Meyer, David H. Kamens, and Aaron Benavot (Washington, DC: Falmer Press, 1992), 6.

29 Daniel Tanner and Laurel Tanner, History of the School Curriculum (New York: Macmillan, 1990). 
the suggestion and do more to foster and make intelligent the fine ideal of British citizenship." 30 And Mark had no doubts that a British citizen was not identical to the American citizen.

It is not difficult to see that the three concepts "citizen," "society," and "nation" especially in their interplay arose at the turn from the eighteenth to the nineteenth century - again, in each country with its respective idiosyncrasy. And it is no coincidence that this is exactly the time period when we can observe a major cultural shift in the Western world that can be labeled "educationalisation of the world." An educationalised world is a world in which not only social problems were and are constantly assigned to education but also a world that defines its very own development and future in an educational language. ${ }^{31}$ The parallel between the rise of the mutual relation between "citizen," "society," and "nation" on the one hand, and the cultural shift to an educationalised world on the other, is no coincidence. That is because the citizens (however they were constructed in their respective political culture) of a nation-state had to be made, for they were not born. ${ }^{32}$ One of the major elements in this educational "making of citizens" was compulsory schooling in the mass school systems.

\section{Constitutions and the creation of citizens}

It is generally acknowledged that the erection of the modern mass school systems has to be seen in close relation to the emerging nation-states mainly in the long nineteenth century between the foundation of the United States of America in 1787 and the foundation of Finland after World War I. Yet, only rather few, if any, published studies focus on the interrelation between the foundation of the (nation-)states and the erection of the modern school systems. That is striking, especially in view of the rise of curriculum studies in the beginning of the twentieth century triggered by the masses of immigrants that had to be "made" Americans via schooling and the curriculum. The prominent progressivist Charles Edward Merriam, professor of political science at the University of Chicago, who had published on The Making of Citizens: A Comparative Study of Methods of Civic Training 33 in 1931 and on Civic Education in the United States ${ }^{34}$ in 1934 had also published on the idea that a constitution is, in today's words, only a text that was in need of being implemented through a moral stance on the part of the citizens, or, as Merriam said, by (unwritten) attitudes. ${ }^{35}$

The large ignorance in education research about constitutions in the interrelation between curriculum and the citizen is striking, because constitutional historians would (of course) have no doubts about the outstanding importance of constitutions, which started to be implemented after the American independence as sets of fundamental principles according to which states should be governed. Constitutions

30 Harry Thiselton Mark, Modern Views on Education (London: Collins' Clear-Type Press, 1913), 44.

31 Daniel Tröhler, Pestalozzi and the Educationalization of the World (New York: Palgrave Pivot, 2013).

32 Thomas S. Popkewitz and Fazal Rizvi, "Globalization and the Study of Education: An Introduction," in Globalization and the Study of Education. 2009 Yearbook of the National Society for Studies in Education, Volume 108, ed. T. S. Popkewitz and F. Rizvi (New York: Wiley, 2010), 21.

33 Charles Edward Merriam, The Making of Citizens: A Comparative Study of Methods of Civic Training (Chicago: University of Chicago Press, 1931).

34 Charles Edward Merriam, Civic Education in the United States (New York: Scribner, 1934).

35 Charles Edward Merriam, The Written Constitution and the Unwritten Attitude (New York: Richard R. Smith, Inc., 1931). 
are expressions of sovereignty, be it in the hand of one, a few persons, or a people. In principle constitutions:

- define and unite a country's inhabitants and transform them into a people, and through that they at the same time identify foreigners as different from citizens,

- $\quad$ specify the rights and duties of all inhabitants (which may not be the same for all of them),

- $\quad$ arrange the basis of political interaction and participation, and

- define the relationship between the political and the religious.

In short, constitutions express (dominant views of) the ideal citizens of a given political entity, they legitimate mechanisms of social distinctions, and at the same time they "contain institutionalized mechanisms of power control for the protection of the interests and liberties of the citizenry, including those that may be in the minority." ${ }^{36}$

The broad ignorance about the constitutions in educational research is at the expense of the quality of the research in education, and this neglect is simply incomprehensible when research addresses questions of citizenship with regard to schooling and curriculum. Constitutions and school laws - and thus curricula - have a threefold relationship:

- On a very formal level, a hierarchy is perceivable, for a school law, like any other law, in any case has to follow the fundamental guidelines defined in the constitution.

- On a more content level, constitution and school laws/curricula are like specification and implementation: Namely, they define and are designed to make the ideal citizens.

- On a more cultural level, though, the two are institutional brothers in arms in the service of traditional enculturated beliefs and values, at least of dominant parts of the societies.

Against this background, cultural path dependencies in the development of the school and its curriculum play a much more important role than a historiography suggesting the idea that school changes with new school laws. The often celebrated liberal school law of Zurich of 1832, for instance, was successful not because it was "brand new," but because it was in harmony with the new constitution of 1831, whereby both the constitution and the school law expressed visions of (local) self-government that are to be traced back to the Zwinglian reformation in the sixteenth century and its ideal of a (Christian) republic. ${ }^{37}$

This idea of path dependencies was known a long time ago, as we can learn from one of the first comparatists in education, the British historian Michael Sadler, who noted that "a national system of education is a living thing, the outcome of forgotten struggles and difficulties and 'of battles long ago'. It has in it some of the secret wor-

36 Scott Gordon, Controlling the State: Constitutionalism from Ancient Athens to Today (Cambridge: Harvard University Press, 1999), 4.

37 Daniel Tröhler, “Classical Republicanism, Local Democracy, and Education: The Emergence of the Public School of the Republic of Zurich, 1770-1870," in Schooling and the Making of Citizens in the Long Nineteenth Century: Comparative Visions, ed. D. Tröhler, T. S. Popkewitz, and D. F. Labaree (New York, Routledge, 2011), 153-76. 
kings of national life." ${ }^{38}$ Curricula reflect - as do constitutions - fundamental, taken for granted "cultural-cognitive" 39 assumptions about the "good life" and the just social order made up by the ideal citizens, whereby precisely because "cultural-cognitive" assumptions rest "on preconscious, taken-for-granted understandings" 40 they exert considerable effects, even though they may be hard to measure using the traditional quantitative methods found in large-scale research designs.

\section{New constitutions and new school laws: European examples}

It is perhaps one of the most frequently overlooked phenomena in education research that people with enough power to create a new constitution were well aware that their construction of an ideal citizenry and social order needed an institution that "made" or redeemed these ideal citizens of a envisaged social order. Among these institutions, the mass public schooling was meant to play a crucial role, and in this respect it did not matter whether or not the nation-states' new constitutions were liberal, heading towards a secular republic, or conservative, protecting nobility, monarchy, the church, or a combination of them, and whether or not the constitutions contained articles concerning education. Yet, passing a new school law did not necessarily mean that the school would have the intended effects, wherefore school reforms that we are so often confronted with in research can be indeed interpreted as attempts to bring schools finally in line with the dominant cultural aspirations standing behind the curricula.

In the European history of the long nineteenth century, it is striking how quickly a new school law was passed after passing a new constitution. The unmatched example is France. In the first 40 years after the Revolution in 1789 new constitutions were adopted in 1791, 1793, 1795, 1799, 1814 (French Charter), and 1830. Almost parallel to this development school laws followed in 1792 (by Condorcet, but not adopted because of the beginning of the Terreur), 1794, 1795, 1802, 1816 (Ordonnance), and 1833 (the famous Guizot law). But that is not the end of the story, as the next 35 years should prove. The Second Republic was founded in 1848 by a new constitution, and a new school law followed in 1850. Louis Bonaparte took over by declaring himself Emperor Napoleon III and decreed a new constitution in 1852, which was followed by a new school law the same year that was adopted in 1854. A new school law followed constitutional changes in 1867, and after the French defeat in the Franco-Prussian War (1870-1871) new constitutional laws followed in 1875, followed by the two important Jules Ferry laws in 1881 (making schools free of charge) and in 1882 (making schools mandatory and secular). In less than 100 years, the French had 10 new constitutions and 10 new school laws (11, if Condorcet's draft law of 1792 is counted).

Indeed, France was the unmatched example, but it was not singular, as can be seen first in the context of Napoleon: The French gave the Batavian Republic its constitution in 1797; a new school law was passed in 1801, followed by the laws of 1803

38 Michael E. Sadler, How Can We Anything of Practical Value from the Study of Foreign Systems of Education? (Guildford, Surrey Advertiser, 1900), 11.

39 William Richard Scott, Institutions and Organizations, 2nd ed. (Thousand Oaks: Sage Publications, 2001), 57.

40 Scott (2001), 61. 
and 1806, the latter being the fundament of the development of not only the Dutch nation-state. The Helvetic Republic got its constitution in 1798, and its school law came into force in 1799 (largely influenced by the plan that Condorcet had presented to the French parliament in 1792). These two revolutionary cases reveal the interconnection between new social and political ideas and the education of the future citizen, as does Belgium, too, which separated from the Netherlands in 1830 and passed a new constitution in 1831, followed by a draft of a comprehensive school law in the same year. ${ }^{41}$ Meanwhile, in 1839, today's Luxembourg, originally a part of segregationist Belgium in 1830, became independent and gave itself a constitution in 1841 and a new school law in 1843, whereby hidden, sometimes amazing and surprising borrowings connected the school laws of France, the Netherlands, Belgium, and Luxembourg, without depriving them of their peculiarities. ${ }^{42}$ Similar developments can be observed in nineteenth century Prussia, Spain, and Austria, too, all embedded in movements of national sentiments. Austria in turn affected the Italian experience, which in turn had some parallels with England and Wales.

As a rule, in all European states passing a new constitution at some point in time passed a new school law within some four or five years, and the latest of these nation-states, Finland, is no exception in this regard. How much the feeling of national sentiment and liberation affected the interrelation between the constitution and the school law may precisely be seen again in Finland, where after centuries of being occupied by Sweden (1249-1809) and then by Russia (1809-1917), the Finns adopted a constitution in July 1919 and passed a comprehensive school law in 1921, which was uniform for everybody, mandatory for everybody, and destined to "create" Finns with an "emphasis on Finnishness" and "patriotism." ${ }^{43}$ The only exception to this rule of new school laws following new constitutions within a few years seems to be the three Scandinavian countries Denmark, Sweden, and Norway, and foremost the two central powers Denmark and Sweden. These Scandinavian countries were characterised by the fact that they all shared the same religion that was dominant in Germany - that is, Lutheranism - but that they at the same time feared the growing political influence of Germany. Furthermore, they were somehow devoted to the unifying idea of Old Norse, the North Germanic language that was spoken by the inhabitants of Scandinavia, and devoted to the Nordic myths as well. ${ }^{44}$ Against this background, the idea of distinct nations that could be combined into a territorial state was more difficult to construct than elsewhere in Europe, which makes the Danish, Swedish, and Norwegian exceptions to the rule that new school laws always followed shortly after passing a constitution that defined the nation-state in its sovereignty.

41 Commission spécial, Projet de loi pour l'enseignement public Belgique, présenté par al commission spécial, créée par arrête du 30 Aout 1831, et publié par le ministre de l'intérieur (Brussels: H. Remy, imprimeur-libraire, 1832).

42 Geert Thyssen, “The Stranger Within: Luxembourg’s Early School System as a European Prototype of Nationally Legitimized International Blends (ca. 1794-1844)," Paedagogica Historica 49, no. 5 (2013), 625-644.

43 Merja Paksuniemi, "The Development of the Finnish Public School from the 1860s to 1920s," unpublished paper presented on occasion of the Sixth Nordic Conference on the History of Education, 20-21 August 2015, Uppsala University, Sweden.

44 Ulrike Hafner, ,Norden' und ,Nation' um 1800: Der Einfluß skandinavischer Geschichtsmythen und Volksmentalitäten auf deutschsprachige Schriftsteller zwischen Aufklärung und Romantik (17401820) (Triest, Edizioni Parnaso, 1996). 
Denmark - which due to the tensions with England was loyal to Napoleon and was therefore defeated in 1814 - adopted a new school law in 1814 with no new constitution until 1849. However, the Danish school law of 1814 was in fact not one unifying law, expressing the national unity and fostering patriotism of the constitutionally defined citizens - as there was no constitution and as a large part of the then Danish people were, linguistically, German - but more of a "series of school laws" for different children according to their social background, the region they lived in, gender, and religion. ${ }^{45}$ Yet, there was a unifying principle of the school laws, but that was directed to loyalty to the Danish King, which at least partly explains the Danish exception between 1814 and 1849, when a new constitution expressed a decidedly national feeling of unity and the school law to follow in 1855 with compulsory education (undervisningspligt) for all was the central concern. ${ }^{46} \mathrm{~A}$ crucial role in this (new) Danish focus on nation (and exceptionalism) seems to have been played by Nikolai Grundtvig's conception of Danish history as holding the mystic essence of the nation, the Volksgeist, the unique spirit assigned to a people as having "spiritual" power for the Danish people. ${ }^{47}$ Danish national(ist) feelings grew over the century and strengthened in particular when in the Second Schleswig War in 1864 Denmark lost to Prussia parts of its southern territory in which the inhabitants spoke predominantly German (and who became Prussian and, after 1871, German). In Denmark now reduced in size and with its mainly Danish-speaking inhabitants, the idea of the nation-state and the making of the national citizen became even more prominent.

Equally "delayed," but taking the somehow "reversed" route as compared to Denmark, was Sweden. Sweden, however, and in contrast to the other European nation-states, did not pass one document as a constitution, but four of them between 1809 and 1812. The underlying cause of the reorganisation was Sweden's defeat against Russia, in which Sweden lost Finland. The defeat strengthened the Swedish nobility, which had been largely deprived of power in the 1772 Instrument of Government (1772 års regeringsform) declared by Gustav III of Sweden that fostered absolute monarchy. Obviously, the first of the constitutional documents adopted in 1809, the new 1809 airs regeringsform, followed by the second in 1810, the Act of Succession (1810 års successionsordning), did not so much assemble the Swedish nation as a nation, as was the case of the continental nation-states, but rather was primarily concerned with power structures of the "common fatherland," as the preamble states. The notion of the nation does not appear in the 1809 arrs regeringsform, and the notion of the Swedish people (Svenska folket) is extremely marginal in contrast to the revision of the definition of the Riksdag of the Estates in 1866, which starts in $\$ 1$ with the notion of the "Swedish people" that is to be represented in the new Riksdag. Against this background, it may not be surprising that in Sweden a new school law was not passed with the 1809 års regeringsform, but at least in 1812 a Committee on Education (Uppfostringskommittén) was established, with proposals to be discussed in the Riksdag, in particular regarding neglected (poor) children (for their own chil-

45 Christian Larsen, Erik Nørr and Pernille Sonne, Da skolen tog form. 1780-1850 (Aarhus: Aarhus Universitetsforlag, 2013).

46 Larsen, Nørr, and Sonne (2013).

47 Alexander Maier, "Bildung zur Nation: Geschichtserzählung und kulturelle Identität als sakral-pädagogisches Programm bei Nikolai Grundtvig," Bildungsgeschichte. International Journal for the Historiography of Education 5, no. 2 (2015), 162-81. 
dren, the elite favored home schooling). In 1825 this committee was followed by the "genius committee" (Snillekommittén), which followed the policy of its predecessor, negotiated between advocates of compulsory education and advocates of home schooling, and accepted public schooling only in cases of distress. ${ }^{48}$ An official first school law was passed only in 1842, after a national crisis had been perceived due to severe crashes in the international economy, followed by public protests and even spontaneous riots in Stockholm in which a number of people were killed. In this emergency the Riksdag reacted towards Swedish vulnerability to external events, and different measures to strengthen the national economy and polity in general were undertaken, which was also the context of the school law to be passed in $1842 \cdot{ }^{49}$ It is still being disputed whether this school law simply "legalised" already existing practices to control the lower classes rather than to form a national unity or if this new school law has to be interpreted as the foundation of modern mass schooling in Sweden..$^{50}$ Deliberate nation building via selected school subjects like history and civics and state-based inspections of schooling seemed to have taken place only in the late nineteenth century, ${ }^{51}$ in a time that was, with regard to territorial politics, decisively anti-German.

Norway in turn was more "continental" than Denmark and Sweden, for it declared its independence immediately after having lost - as an ally of Denmark - the Napoleonic War in 1814 by adopting a constitution right before it was invaded by the Swedes. In a compromise, the Norwegians accepted the Swedish monarch as "their" king, and in turn the Swedes accepted the comparatively liberal Norwegian constitution, and in the same year, debates on educational reforms in Norway began. A parliamentary law commission was appointed in 1814, and proposals were presented to the parliament several times, leading to the acceptance of a preliminary school law in $1816 . .^{52}$ More Latin schools were founded, under the control of the state (and not the bishop), but the first comprehensive Norwegian school law was actually passed only in 1827, 13 years after the passing of the constitution, serving the idea of creating a national unity. A detailed curriculum with instructions for teachers was to follow in $1834^{53}$; it represented a cultural attitude that has been called Norwegian "Romantic Nationalism." ${ }^{54}$

Even though the Scandinavian countries Denmark, Sweden, and Norway are

48 John Boli, New Citizens for a New Society: The Institutional Origins of Mass Schooling in Sweden (Oxford: Pergamon Press, 1989), 214.

49 Boli (1989), 217.

50 Esbjörn Larsson, "On the Use and Abuse of History of Education: Different Uses of Educational History in Sweden," in Knowledge, Politics and the History of Education, ed. Jesper Eckhardt Larsen (Berlin, Lit, 2012), 106; Johannes Westberg, "The School Act of 1842 and Emergence of Mass Schooling in Sweden," unpublished paper presented on occasion of the Sixth Nordic Conference on the History of Education, 20-21 August 2015, Uppsala University, Sweden.

51 Jakob Evertsson, "History, Nation and School Inspections: The Introduction of Citizenship Education in Elementary Schools in Late Nineteenth-Century Sweden," History of Education 44, no. 3 (2015), 259-73.

52 Val D. Rust, The Democratic Tradition and the Evolution of Schooling in Norway (New York: Greenwood Press, 1989), 37.

53 See, in this volume, Tone Skinningsrud and Randi Skjelmo, "From Regional Differentiation Towards National Uniformity: The Norwegian Elementary School Acts of 1739 and 1827," Nordic Journal of Educational History 3, no.1 (2016).

54 Rust (1989), 47. 
somewhat different from Finland and the continental countries, they all show concern for a state-organised educational policy with regard to nation building, and the difference - especially apparent in the North - indicates the distinct historical trajectories in creating the respective loyal citizens.

\section{Cultural agendas, curricula and the loyal citizens}

To postmodernist scholars the idea of a constitution as basic text of a social order may seem old-fashioned, because schooling is less about normative ordering by elites and more about how students are to become changed into future citizens while at school. Although it is generally accepted today that normative sources (for instance, laws about schooling) do not tell us too much about classroom reality (as the enacted and experienced curriculum), it still has to be noted that constitutions and laws are a (part of the total) reality and that they may change, if it is registered that actual practices are, for whatever reason, too far from the envisaged ideal.

And it made a very great difference indeed for real life in the social order, for instance, whether a constitution - here the 1809 års regeringsform - was decreed in the "name of God Almighty," describing the monarch as "sacred" (\$3) and defining in $\$ 2$ that the monarch had to be part of the "pure Evangelical doctrine" as defined during the Uppsala Synod in 1593, whereby $\$ 6$ defined four secretaries of state, one mandated with "religion, clergy, public education and the poor" (religious freedom was guaranteed, $\$ 16$ ), or if, 11 years previously, in 1798, Article 2 of the Helvetic Republic states: "The totality of the citizens is the sovereign" and that freedom of religion is guaranteed (Article 6) and the "two pillars of the public good are security and the Enlightenment," whereby the "Enlightenment is preferable to prosperity" (Article 4). Given today's skepticism towards intellectual history and normative sources, it is important to note that these were not word games with no relevance for daily life. They expressed dominant cultural convictions that were reflected in the curriculum, which not only included a selection of structured knowledge but also was organised in different school levels and school tracks with different, more or less meritocratic transition regimes, preparing social stratification via selection. To be a citizen - explicitly or not - was not simply to be a citizen in a formal sense, and it is exactly here that the need to contextualise - or re-contextualise - the interim de-contextualised floating signifier of "the citizen" becomes relevant.

Here it is important to see that progressive school administration and innovative pedagogy are not necessarily indicators of a progressive or liberal constitution, or vice versa, as can be easily demonstrated with the case of Prussia. Even though Prussia was admired for its education system, there were reservations about compatibility, precisely because the Prussian system was embedded in a conservative political culture. As Hughes pointed out in 1902: “The discipline of the German school is admirable, so is the general system of training - for German children; yet there can be no doubt that such a system would be the very worst for English or American children." ${ }^{55}$ Loyalty to the unifying nation was one aspect of the educational fabric, and loyalty to social distinctions another. The Prussian school system therefore foresaw for wealthier parents a school charging fees that ran parallel to the free elementary

55 Robert E. Hughes, The Making of Citizens: A Study in Comparative Education (London: Walter Scott Publishing, 1902), 11. 
school; this "prep school" (Vorschule) - "prep school" understood here as the preparation or preliminary stage leading to the Gymnasium, with the career gatekeeper Latin in the core of its syllabus - excluded almost all of the schooled children who went to the public school free of charge.

The national strategies for social distinctions become evident in the institutionalisation of different school tracks, in particular on the secondary school level. Here, Luxembourg may serve as an example and an example of present days. On its secondary level, Luxembourg has a tracked secondary school system, divided into a more prestigious level, the classical upper high school (lycée classique), and the less prestigious level, the technical upper high school (lycée téchnique). Whereas the teaching language in the classical upper high school (lycée classique) is French, the teaching language in the technical upper high school (lycée téchnique) is German. This leads to the fact that, for instance, in history class, students at technical upper high schools use textbooks made in Germany, whereas students at classical upper high schools use history textbooks made in France. So far there has been no research on the different views of history (and a troubled past) that these curricular differences produce.

These differences gain even further relevance when it is realised that Luxembourg decrees that its only official legal language is French, despite the fact that Luxembourgers' vernacular language is Luxembourgish, a Moselle Franconian dialect - that is, a German dialect. Hence, Luxembourg's constitution and all its laws are uniquely written in rather stilted legalistic French and not in all the official languages to which Luxembourg is committed. Evidently, the formal tracking of the secondary school level and the different teaching languages is, beyond all questions of content or syllabus or course of study, a curricular element of social reproduction as an expression of the dominant vision of social and political order. It is not surprising, then, that only $1 / 3$ of a student cohort would be admitted to the more prestigious classical upper high school (lycée classique) and 2/3 to the less prestigious technical upper high school (lycée téchnique). Nor is it surprising that almost 80 per cent of the students at the more prestigious classical upper high school are of Luxembourgish origin and only 20 per cent foreign born, and that at the less prestigious technical upper high school foreign-born students make up almost 50 per cent of a cohort. And the pictures changes even dramatically to the disadvantage of foreign-born students, if we consider the lowest tracks within the less prestigious technical upper high school (lycée téchnique). ${ }^{56}$

\section{Transnationalism and curriculum history as an academic field}

At the beginning of this article, it was suggested that curriculum history in particular offers a sophisticated way to do educational research, particularly as it allows the combination of traditionally separated philosophical history of ideas (for instance, social justice or political philosophy), social history (for instance, with regard to educational opportunities and life chances) and the history of institutions, if this

56 Ministère de l'Éducation nationale, de l'Enfance et de la Jeunesse, Service des Statistiques et Analyses \& Université du Luxembourg, FLSHASE (Faculté des Lettres, des Sciences humaines, des Arts et des Sciences de l'Education), Bildungsbericht Luxemburg 2015. Band 1: Sonderausgabe der Chiffres Clés de l'Éducation Nationale 2013/2014 (Luxembourg: MENJE/Service des Statistiques et Analyses et Université du Luxembourg, 2015). 
integrated view is understood as part of a cultural history that asks for particular systems of reasoning and modes of sense-making that emerge and may prevail (or not) in areas and regions, whereby very often the idea of the nation-state has more or less successfully defined where these areas and regions are to be defined geographically. Furthermore, this approach makes possible an international and comparative perspective that does not suffer from hegemonic visions, as the neo-institutional assumption of a world culture does. That assumption, in the end, does not analyse phenomena of globalisation but in fact globalises them by imagining one, grand, centuries-old world narrative of globalisiation. ${ }^{57}$

The precondition then is to de-contextualise the concepts of citizen, nation, and curriculum, and at least partly the concept of constitution. This de-contextualisation allows us to see the particular in the overall scheme as something particular and not as a role model to be imitated. Against that background, the statistically verified existence of school subjects gives both a distorted and an overgeneralised picture of history. At least as important as the formal existence of school subjects are:

- $\quad$ school structures

- school tracks

- regimes of control (inspection, etc.)

- transition regimes

- $\quad$ stratification and inclusion/exclusion mechanisms

- the order of school subjects (in the syllabus and in the weekly timetable)

- the selected and arranged contents in the curricular guidelines and in the textbooks or schoolbooks.

In addition, extra-curricular activities offered by the schools, such as (foremost in the United States) particular athletic programs, drama clubs, or marching bands, belong to these factors, and equally important are school uniforms, ${ }^{58} \mathrm{school} \mathrm{rituals,}{ }^{59}$ or the public marching of (male) school youth in a parade in the King's Garden in Stockholm, expressing military devotion to both higher education and the monarchy. ${ }^{60}$ All of these rituals constitute "curriculum" in its historical development within the context of the nation-states (or regions within them, such as in Germany or Switzerland) - exposed to international challenges and transnational imports and exports - unifying people as a national "we" and as citizens and non-citizens or for-

57 Daniel Tröhler, "Globalizing Globalization: The Neo-Institutional Concept of a World Culture," in Globalization and the Study of Education, 2009 Yearbook of the National Society for Studies in Education, Volume 108, ed. Thomas S. Popewitz and Fazal Ritzvi (New York: Wiley, 2009), 29-48.

58 Nathan Joseph, Uniforms and Nonuniforms: Communication Through Clothing (New York: Greenwood Press, 1986).

59 Peter McLaren, Schooling as a Ritual Performance: Towards a Political Economy of Educational Symbols and Gestures (London: Routledge \& Keagan Paul, 1986); Christoph Wulf and Jörg Zirmas, eds., Innovation und Ritual: Jugend, Geschlecht und Schule, Zeitschrift für Erziehungswissenschaft 7, 2004 (Beiheft 2).

60 Henrik Meinander, Towards a Bourgeois Manhood (Helsinki, Societas Scientiarum Fennica, 1994), 178. At the same time this ritual refers to specific gender roles in Sweden towards the end of the nineteenth century, according to which masculinity was more backward-oriented and therefore conservative, also with regard to gender stereotypes, whereas the (bourgeois) woman was more prospective and tended towards emancipation, see Sara Backman Prytz, Borgerlighetens döttrar och söner. Kvinnliga och manliga ideal bland läroverksungdomar, ca. 1880-1930 (Uppsala: Uppsala University, 2014). 
eigners, stratifying them socially into different categories, such as gender, class, and talent, and distinguishing them from others.

Against this background, curriculum history needs to pay attention not only to the "usual suspects" among the school subjects, such as history or civics, but also to previously rather marginalised items such as music, ${ }^{61}$ allegedly neutral mathematics, ${ }^{62}$ or presumed harmless physical education, which in England was part of the education of the gentleman, in Prussia part of the education of a strong, willing, and executing soldier as subject, and in Switzerland as part of civic education of the militia's citizen-soldier. Besides these various individual school subjects, the depicted hierarchy of the school subjects in the timetables deserves special attention, with religion at the top for a very long time, then languages, math, history and geography, and, always in last place, physical education and home economics for girls, reflecting the late and sometimes very late implementation of women's suffrage in the nation-states. The hierarchy is neither alphabetical nor does it follow the quantitative allocations of the weekly lessons, but it does express cultural values. Religion is of particular interest, for it dominated the curricular hierarchy even long after religious education had in some places been declared voluntary.

The American cultural anthropologist Margaret Mead is said to have once noted, "If a fish were to become an anthropologist, the last thing it would discover would be water." ${ }^{63}$ The water that we do not so easily discover is religion in its different aspects and its amalgam with the nation-state. In particular, Protestantism has culturally induced that education is not only understood as solution to any kind of perceived social problems, from teen pregnancy to pollution, but as a fundamental way of making sense of the (modern) world and the (modern) self. ${ }^{64}$ That the two major Protestantisms, Swiss Reformed Protestantism and German Lutheranism, were able to connect themselves to the emerging nation-states in the long nineteenth century has led to this most particular interdependence between salvation and schooling, exceeding the business of teaching to write, read, and calculate by far. The very idea that nation-state citizens can be "made", that they actually will feel that they are a part of a national community, ${ }^{65}$ in this respect equal to other members and distinct from "foreigners," that they will accept social distinctions, and that they are completely convinced that better and more education will place a person in a more privileged social position expresses this salvation narrative that seems to be at hand only and exclusively in the realm of organised schooling in a nation-state.

The educational sciences were very good children of this salvation narrative as they developed in the respective nation-states. They legitimised themselves by con-

61 Ruth I. Gustafson, Race and Curriculum: Music in Childhood Education (New York: Palgrave, 2009).

62 Jennifer De Net Diaz, "Signs of In/equality: A History of Representation and Reform in Elementary School Mathematics from the 1950 s to the Present" (PhD diss., University of Wisconsin-Madison, 2014). http://gradworks.umi.com/36/18/3618043.html.

63 George D. Spindler, ed., Doing the Ethnography of Schooling: Educational Anthropology in Action (New York: Holt, 1982), 24.

64 Daniel Tröhler, "Educationalization of the Modern World," in Encyclopedia of Educational Philosophy and Theory, ed. Michael A. Peters (Dordrecht: Springer, in press).

65 See, for instance, the example of history and geography in Switzerland: Nathalie Dahn and Lukas Boser, "Learning to See the Nation-State: History, Geography and Public Schooling in Late 19th Century Switzerland," Bildungsgeschichte. International Journal for the Historiography of Education 5, no. 1 (2015), 41-56. 
tributing mostly unconsciously to the redeeming of the promises and expectations concerning the national citizens and to the denominational roots by formulating educational theories aiming at, in one case, the virtuous citizen, and, in the other case, Bildung, and by developing the organisation of schooling in the frame of the notions of curriculum or Didaktik. In either way, they provide often empirical data pertaining to educationalised questions such as social inequality, new media, disability, multiculturalism, multilingualism, tolerance, sustainability, entrepreneurship, development, and the like, and they suffer from what is called in German Geschichtsvergessenheit, fundamental unawareness of one's own historicity.

There is, of course, no Archimedean point to analyse these different national and Protestant trajectories in the realm of the individual nation-states. But it seems that an approach by curriculum history that is not in placed in the ideological tradition that it emerged from and that operates with floating signifiers like nation, society, citizen in order to compare their respective distinct way of historical materialisation in the realm of the emerging nation-states (and today in the realm of the globalised vision of the OECD or other transnational organisation) is a promising way to emancipate educational research from the salvation narratives that were institutionalised in the education systems of the nation-states, to which the educational sciences belong. It would be a process of self-enlightenment about not so enlightened roots of our role as educational researchers; it would necessarily be historical, comparative, interdisciplinary, and by that, revealing, appealing, and very interesting, contributing to a European education history that respects national or cultural distinctions without getting trapped by national idiosyncrasies. 


\section{References}

Autio, Tero. Between and Beyond the German Didaktik and Anglo-American Curriculum Studies. Mahwah: Lawrence Erlbaum Associates, 2006.

Backman Prytz, Sara. Borgerlighetens döttrar och söner: Kvinnliga och manliga ideal bland läroverksungdomar, ca. 1880-1930. Uppsala: Uppsala University, 2014.

Boli, John. New Citizens for a New Society: The Institutional Origins of Mass Schooling in Sweden. Oxford: Pergamon Press, 1989.

Caswell, Holis L. and Doak S. Campbell. Curriculum Development. New York: American Book Company, 1935.

Commission spécial. Projet de loi pour l'enseignement public Belgique, présenté par al commission spécial, créée par arrête du 30 Aout 1831, et publié par le ministre de l'intérieur. Brussels, Belgium: H. Remy, imprimeur-libraire, 1832.

Dahn, Nathalie and Lukas Boser. "Learning to See the Nation-State - History, Geography and Public Schooling in Late nineteenth Century Switzerland." Bildungsgeschichte. International Journal for the Historiography of Education 5, no. 1 (2015), 41-56.

Diaz, Jennifer De Net. "Signs of In/equality: A History of Representation and Reform in Elementary School Mathematics from the 1950s to the Present." PhD diss., University of Wisconsin-Madison, 2014. http://gradworks.umi.com/36/18/3618043. html

Dole, Charles Fletcher. The American Citizen. Boston: D. C. Heath, 1892.

Evertsson, Jakob. "History, Nation and School Inspections: The Introduction of Citizenship Education in Elementary Schools in Late Nineteenth-Century Sweden." History of Education 44, no. 3 (2015), 259-73.

Gordon, Scott. Controlling the State: Constitutionalism from Ancient Athens to Today. Cambridge: Harvard University Press, 1999.

Gundem, Bjørg B. "Understanding European Didactics.” In Routledge International Companion to Education, edited by Bob Moon, Sally Brown, and Miriam BenPeretz, 235-62. London: Routledge, 2000.

Gustafson, Ruth I. Race and Curriculum: Music in Childhood Education. New York: Palgrave, 2009.

Hafner, Ulrike. ,Norden' und ,Nation' um 1800: Der Einfluß skandinavischer Geschichtsmythen und Volksmentalitäten auf deutschsprachige Schriftsteller zwischen Aufklärung und Romantik (1740-1820). Triest: Edizioni Parnaso, 1996.

Hamilton, David. Towards a Theory of Schooling. Philadelphia: Falmer Press, 1989.

Hamilton, Joseph Gregoire de Roulhac and Edgar W. Knight. The Making of Citizens. Chicago: McClurg \& Co., 1922.

Hopmann Stefan and Kurt Riquarts. Didaktik und, oder Curriculum: Grundprobleme einer internationalen vergleichenden Didaktik. Weinheim: Beltz, 1995.

Hopmann Stefan and Bjørg B. Gundem. "Didaktik Meets Curriculum: Towards a New Agenda," in Didaktik and/or Curriculum: An International Dialogue, edited by Bjørg B. Gundem and Stefan Hopmann, 331-54. Frankfurt, Peter Lang, 1998).

Horlacher, Rebekka. The Educated Subject and the German Concept of Bildung: A Comparative Cultural History. New York: Routledge, 2016.

Horlacher Rebekka and Andrea De Vincenti. "From Rationalist Autonomy to Scientific Empiricism: A History of Curriculum in Switzerland." In International Handbook of Curriculum Research, 2nd ed., edited by William F. Pinar, 467-92. New York: Routledge, 2013. 
Hughes, Robert E. The Making of Citizens: A study in Comparative Education. London: Walter Scott Publishing, 1902.

Humboldt, Wilhelm von. "Der Königsberger und Litauische Schulplan.” In Schriften zur Politik und zum Bildungswesen, Vol. IV of Wilhelm von Humboldt: Werke in fünf Bänden, 168-95. Darmstadt: Wissenschaftliche Buchgesellschaft, 1963 (1809).

Joseph, Nathan. Uniforms and Nonuniforms: Communication Through Clothing. New York: Greenwood Press, 1986.

Klafki, Wolfgang. "Didaktische Analyse als Kern der Unterrichtsvorbereitung." Die deutsche Schule 50 (1958), 450-72.

Jefferson, Thomas. "Letter to John Banister Jr., dated 15 October 1785." In Thomas Jefferson: Writings, ed. M. D. Peterson, 837-40. New York: Literary Classics of the United States, 1984.

Larsen, Christian, Nørr, Erik and Pernille Sonne. Da skolen tog form: 1780-1850. Aarhus: Aarhus Universitetsforlag, 2013.

Larsson, Esbjörn. "On the Use and Abuse of History of Education: Different uses of educational history in Sweden." In Knowledge, Politics and the History of Education, edited by Jesper Eckhardt Larsen, 105-19. Münster: Lit, 2012.

Lybarger, Michael. "Origins of the Modern Social Studies: 1900-1916." History of Education Quarterly 23, no. 4 (1983), 455-68.

Maier, Alexander. "Bildung zur Nation. Geschichtserzählung und kulturelle Identität als sakral-pädagogisches Programm bei Nikolai Grundtvig." Bildungsgeschichte. International Journal for the Historiography of Education 5, no. 2 (2015), 162-81.

Mark, Harry Thiselton. Modern Views on Education. London: Collins' Clear-Type Press, 1913.

McLaren, Peter. Schooling as a Ritual Performance: Towards a Political Economy of Educational Symbols and Gestures. London: Routledge \& Keagan Paul, 1986.

Meinander, Henrik. Towards a Bourgeois Manhood. Helsinki: Societas Scientiarum Fennica, 1994.

Merriam, Charles Edward. The Making of Citizens: A Comparative Study of Methods of Civic Training. Chicago: University of Chicago Press, 1931.

Merriam, Charles Edward. Civic Education in the United States. New York: Scribner, 1934.

Merriam, Charles Edward. The Written Constitution and the Unwritten Attitude. New York: Richard R. Smith, Inc., 1931.

Meyer, John. "Introduction." In School Knowledge for the Masses: World Models and National Primary Curricular Categories in the Twentieth Century, edited by John W. Meyer, David H. Kamens, and Aaron Benavot, 1-16. Washington, DC: Falmer Press, 1992.

Ministère de l'Éducation nationale, de l'Enfance et de la Jeunesse, Service des Statistiques et Analyses \& Université du Luxembourg, FLSHASE (Faculté des Lettres, des Sciences humaines, des Arts et des Sciences de l'Education), Bildungsbericht Luxemburg 2015. Band 1: Sonderausgabe der Chiffres Clés de l'Éducation Nationale 2013/2014. Luxembourg: MENJE/Service des Statistiques et Analyses et Université du Luxembourg, 2015.

NSSE. Foundations and Technique of Curriculum Construction. Bloomington: Public School Publishing Company, 1926. 
Paksuniemi, Merja. "The Development of the Finnish Public School from the 1860s to 1920s." Unpublished paper presented on occasion of the Sixth Nordic Conference on the History of Education, 20-21 August 2015, Uppsala University, Sweden.

Pinar, William F. The Character of Curriculum Studies: Bildung, Currere, and the Recurring Question of the Subject. New York: Palgrave Macmillan, 2011.

Pinar, William F. What is Curriculum Theory? 2nd ed. New York: Routledge, 2012.

Popkewitz, Thomas S. and Rizvi, Fazal. "Globalization and the Study of Education: An Introduction." In Globalization and the Study of Education: 2009 Yearbook of the National Society for Studies in Education, Volume 108, edited by Thomas S. Popkewitz and Fazal Rizvi, 7-28. New York, NY: Wiley, 2010.

Rush, Benjamin. "Of the mode of Education Proper in a Republic." In The Selected Writings of Benjamin Rush, edited by Dagobert D. Runes, 90-100. New York: Philosophical Library, 1947 (1786).

Rust, Val D. The Democratic Tradition and the Evolution of Schooling in Norway. New York: Greenwood Press, 1989.

Sadler, Michael E. How can we Learn Anything of Practical Value from the Study of Foreign Systems of Education? Guildford: Surrey Advertiser, 1900.

Scott, William R. Institutions and Organizations, 2nd ed. Thousand Oaks: Sage Publications, 2001.

Skinningsrud Tone and Randi Skjelmo. "From Regional Differentiation towards National Uniformity: The Norwegian Elementary School Acts of 1739 and 1827," Nordic Journal of Educational History 3, no. 1 (2016) (this issue).

Spindler George D., ed. Doing the Ethnography of Schooling: Educational Anthropology in Action. New York: Holt, 1982.

Tanner Daniel and Laurel Tanner. History of the School Curriculum. New York: Macmillan, 1990.

Thyssen, Geert. "The Stranger Within: Luxembourg's Early School System as a European Prototype of Nationally Legitimized International Blends (ca. 1794-1844)." Paedagogica Historica 49, no. 5 (2013), 625-44.

Tröhler, Daniel. "Between Ideology and Institution: The Curriculum of Upper-Secondary Education." Journal of Curriculum Studies 41 (2009), 393-408.

Tröhler, Daniel. "The technological sublime and social diversity: Chicago pragmatism as response to a cultural construction of modernity." In Pragmatism and Modernities, edited by Daniel Tröhler, Thomas Schlag, and Fritz Osterwalder , 25- 44. Rotterdam: Sense Publishers, 2010.

Tröhler, Daniel. "Globalizing Globalization: The Neo-Institutional Concept of a World Culture." In Globalization and the Study of Education, 2009 Yearbook of the National Society for Studies in Education, Volume 108, edited by Thomas S. Popewitz and Fazal Ritzvi, 29-48. New York: Wiley, 2009.

Tröhler, Daniel. Languages of Education: Protestant Legacies, National Identities, and Global Aspirations. New York, Routledge, 2011.

Tröhler, Daniel. "Classical Republicanism, Local Democracy, and Education: The Emergence of the Public School of the Republic of Zurich, 1770-1870." In Schooling and the Making of Citizens in the Long Nineteenth Century: Comparative Visions, edited by Daniel Tröhler, Thomas S. Popkewitz, and David F. Labaree, 153-76. New York: Routledge, 2011. 
Tröhler, Daniel. Pestalozzi and the Educationalization of the World. New York: Palgrave Pivot, 2013.

Tröhler, Daniel. "Curriculum History or the Educational Construction of Europe in the Long Nineteenth Century." European Educational Research Journal 15, no. 3 (2016), 279-97.

Tröhler, Daniel. "Educationalization of Social Problems and the Educationalization of the Modern World." In Encyclopedia of Educational Philosophy and Theory, edited by Michael A. Peters. Dordrecht: Springer (in press), doi: 10.1007/978981-287-532-7_8-1.

Westberg, Johannes. "The School Act of 1842 and Emergence of Mass Schooling in Sweden." Unpublished paper presented on occasion of the Sixth Nordic Conference on the History of Education, 20-21 August 2015, Uppsala University, Sweden.

Westbury, Ian, Stefan Hopmann and Kurt Riquarts, eds. Teaching as a Reflective Practice: The German Didaktik Tradition. Mahwah: Lawrence Erlbaum Associates, 2000.

Woellner, Frederic. P. Education for Citizenship in a Democracy: A Text-book for Teachers in the Elementary Schools. New York: Charles Scribner's Sons, 1923.

Wulf Christoph and Jörg Zirmas, eds. "Innovation und Ritual: Jugend, Geschlecht und Schule." Zeitschrift für Erziehungswissenschaft 7 (2004) (Beiheift 2). 